\title{
Large clot splitting the left atrium into two distinct cavities: a report through mitral stenosis transoesophageal echocardiography
}

\author{
Padmakumar Ramachandran, ${ }^{1}$ Sridevi Prabhu, ${ }^{2}$ Jyothi Samanth, ${ }^{1}$ M Sudhakar Rao ${ }^{1}$
}

${ }^{1}$ Department of Cardiology, KMC, Manipal, Karnataka, India

${ }^{2}$ Department of Cardiology, CVT, School of Allied Health Sciences, Manipal, Karnataka, India

\section{Correspondence to} Dr M Sudhakar Rao, msudhakar88@gmail.com

Accepted 20 March 2016
CrossMark

To cite: Ramachandran $P$, Prabhu S, Samanth J, et al. BMJ Case Rep Published online: [please include Day Month Year] doi:10.1136/ bcr-2016-214593

\section{DESCRIPTION}

A 53-year-old woman diagnosed with rheumatic mitral stenosis (at the age of 40 years) presented with worsening dyspnoea New York Heart Association class III of 1 month duration. She was on regular treatment with diuretics, $\beta$-blockers and warfarin (in view of valvular atrial fibrillation). However, 1 month prior to presentation, she was off all medications except warfarin, which she was compliant on. Blood investigations revealed the presence of subclinical hypothyroidism with an optimal international normalised ratio of 2.64. ECG showed atrial fibrillation with a fast ventricular rate. Echocardiography parameters were suggestive of severe mitral stenosis with atrial fibrillation. Transesophageal echocardiography (TEE) showed a large clot in the left atrial (LA) appendage, attached to the LA roof and traversing towards the opposite wall (figures 1 and 2). The patient was advised mitral valve replacement with the LA clot removal, as she had a huge LA clot despite being on optimal anticoagulation.

LA clot is common in severe rheumatic mitral stenosis, with incidence of approximately $15 \%,{ }^{1}$ however, prevalence increases twofold in the presence of atrial fibrillation. In the literature, LV clots have been described with respect to different sites and also as being not attached to the LA mural endocardium. $^{2}{ }^{3}$ In the present case, the patient had severe mitral stenosis with atrial fibrillation and a large clot in the LA appendage, attached to the LA wall and forming a bridge connecting to the

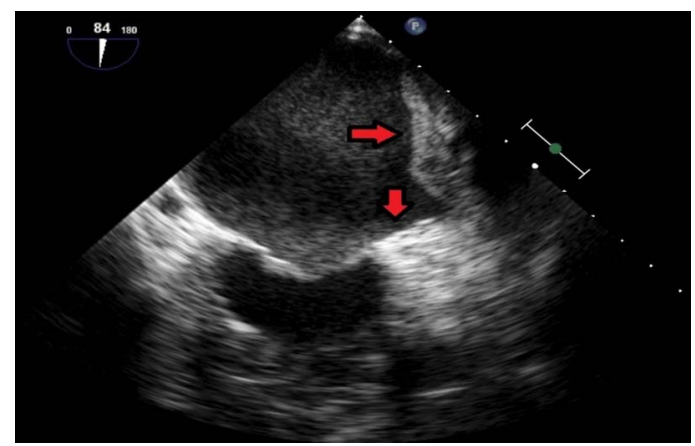

Figure 1 Transesophageal echocardiogram in $84^{\circ}$ view showing clot in the left atrial (LA) appendage, extending to the LA roof (red arrow).

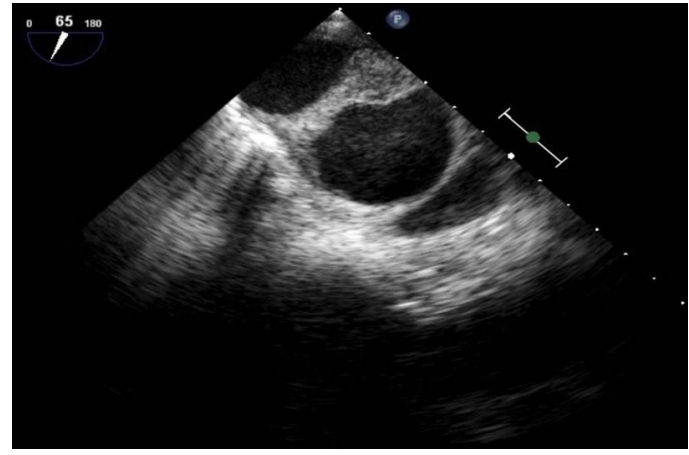

Figure 2 Transesophageal echocardiogram in $65^{\circ}$ view showing a large clot in the left atrial (LA) appendage, attached to the LA roof and traversing towards the opposite wall.

opposite wall. The clot appeared as a partition resulting in two distinct LA cavities on TEE.

\section{Learning points}

A left atrial (LA) clot in the presence of mitral valve disease is often focal in most cases.

- The present case had a huge non-focal clot confined to a plane of the LA body, partitioning the LA into two separate cavities, the rarest of its kind.

Twitter Follow Msudhakar Rao at @suds

Contributors JS and SP wrote the article, PR edited the article and MSR submitted the article.

Competing interests None declared.

Patient consent Obtained.

Provenance and peer review Not commissioned; externally peer reviewed.

\section{REFERENCES}

1 Mahmood ul Hassan, Hussain C, Gul AM, et al. Frequency of left atrial and appendage clot in patients with severe mitral stenosis. J Ayub Med Coll Abbottabad 2010;22:40-2.

2 Manjunath $\mathrm{CN}$, Srinivasa KH, Ravindranath KS, et al. Balloon mitral valvotomy in patients with mitral stenosis and left atrial thrombus. Catheter Cardiovasc Interv 2009;74:653-61.

3 Roberts CS, Roberts WC. Huge, unattached left atrial thrombus in mitral stenosis. Clin Cardiol 1990;13:295-7. 


\section{Images in...}

Copyright 2016 BMJ Publishing Group. All rights reserved. For permission to reuse any of this content visit http://group.bmj.com/group/rights-licensing/permissions.

BMJ Case Report Fellows may re-use this article for personal use and teaching without any further permission.

Become a Fellow of BMJ Case Reports today and you can:

- Submit as many cases as you like

- Enjoy fast sympathetic peer review and rapid publication of accepted articles

- Access all the published articles

- Re-use any of the published material for personal use and teaching without further permission

For information on Institutional Fellowships contact consortiasales@bmjgroup.com

Visit casereports.bmj.com for more articles like this and to become a Fellow 